The Bride and the Dowry 
This page intentionally left blank 


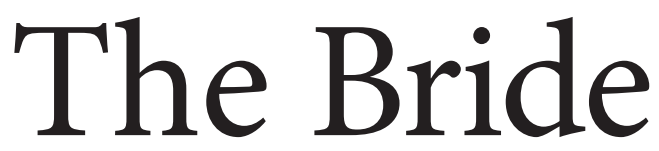

\title{
and
}

\section{the Dowry}

Israel, Jordan,

and the Palestinians

in the Aftermath

of the June 1967 War

\author{
A V I RAZ
}

Yale

UNIVERSITY PRESS

New Haven and London 
Copyright (c) 2012 by Avi Raz.

Maps by Yoram Neeman, copyright (C) 2012 by Yoram Neeman.

All rights reserved.

This book may not be reproduced, in whole or in part, including illustrations, in any form (beyond that copying permitted by Sections 107 and 108 of the U.S. Copyright Law and except by reviewers for the public press), without written permission from the publishers.

Yale University Press books may be purchased in quantity for educational, business, or promotional use. For information, please e-mail sales.press@yale.edu (U.S. office) or sales@yaleup.co.uk (U.K. office).

Set in Minion type by Westchester Book Group. Printed in the United States of America.

Library of Congress Cataloging-in-Publication Data

Raz, Avi.

The bride and the dowry : Israel, Jordan, and the Palestinians in the aftermath of the June 1967 War / Avi Raz.

p. $\mathrm{cm}$.

Includes bibliographical references and index.

ISBN 978-0-300-17194-5 (cloth : alk. paper) 1. Israel-Arab War, 1967-Influence. 2. Arab-Israeli conflict-1967-1973. I. Title.

$$
\begin{gathered}
\mathrm{DS}_{127.85} \mathrm{R}_{39} 2 \mathrm{O} 12 \\
956.04^{\prime} 6-\mathrm{dc} 23 \\
2011049008
\end{gathered}
$$

A catalogue record for this book is available from the British Library.

This paper meets the requirements of ANSI/NISO Z39.48-1992 (Permanence of Paper). 
"What could I do! Facts are such horrid things!" Jane Austen, Lady Susan

"The past is never dead. It's not even past." William Faulkner, Requiem for a Nun 
This page intentionally left blank 